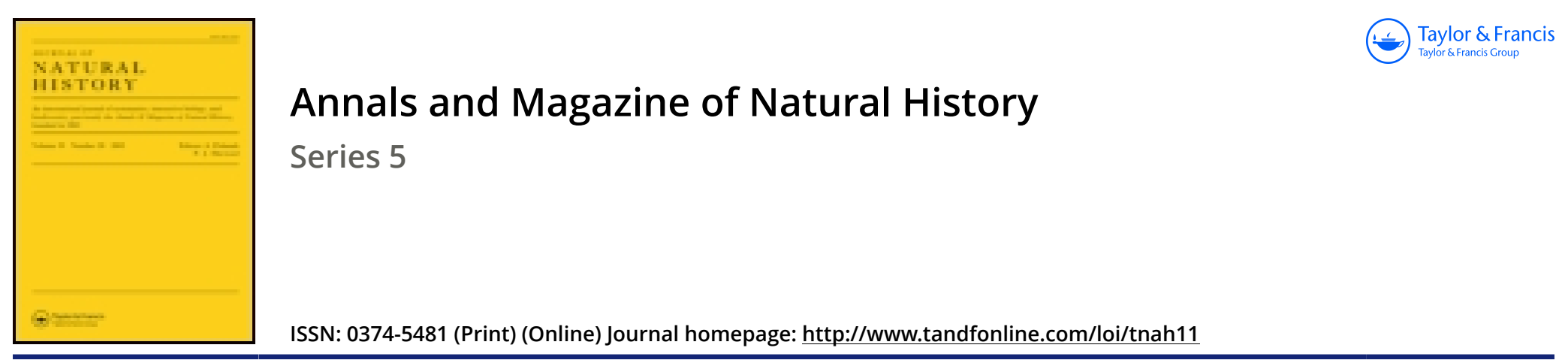

\title{
The Cæciliæ
}

\section{Prof. W. Peters}

To cite this article: Prof. W. Peters (1880) The Cæciliæ, Annals and Magazine of Natural History, 5:27, 263-265, DOI: 10.1080/00222938009459422

To link to this article: http://dx.doi.org/10.1080/00222938009459422

$$
\text { 册 Published online: } 07 \text { Oct } 2009 .
$$

Submit your article to this journal

LII Article views: 5

Q View related articles 두 
Description of Sigerpes occidentalis, the Type of a new Genus of Mantodea from West Africa. By J. Wood-Mason.

In this short paper a new species of Mantodea closely related to the East-African Sibylla tridens, Saussure, is described and made the type of a new genus, Sigerpes, which must be placed in the subfamily Harpagidæ next to the genera Oxypilus and Hestics.

The cephalic horn, as was suspected by the author (P.A.S. B. $1876)$, turns out to be rudimentary in the males.

The new species, described from a fine dried female specimen in the British Mnseum from the neighbourhood of Sierra Leone, differs from Sigerpes (olim Sibylla) tridens $P$ in having the cephalic horn somewhat longer and without lateral lobes and teeth, the base of the wings greenish yellow, the fore tibix more numerously toothed, the fore femora on the inside red tipped with black, and the extremities of the organs of flight not so obviously truncate.-Proc. As. Soc. Beng. November 1879.

\section{The Cæciliæ. By Prof. W. Petzrs.}

Professor Peters has published an important paper on this curious group of Amphibians, in which, after discussing certain critical points, he gives a new division of the known forms into genera, and describes several new species. He finds that his Gymnopis multiplicata (Monatsber. Berl. Akad. 1874) is generically identical with Duméril's Rhinatrema unicolor, and that the characters given by the latter author for his genus Rhinatrema are erroneous as applied to this species; while the Coccilia bivittata of Cuvier, which was referred by Duméril to the genus Rhinatrema, is founded upon immature examples of the Linnean Cacilia glutinosa. Accordingly he sinks the genus Rhinatrema altogether, and retains his own name Gymnopis for the genus including his and Duméril's species.

For the division of the Cæcilix into genera he considers that the position of the tentacular pore alone leads to very unsatisfactory and unnatural results, as, independent of the structure of the skull and viscera, the structure or absence of the dermal scales, the dentition, especially of the lower jaw, and the differences in the form of the tentacle, seem to him to be of much greater importance. The tentacle occurs under three different forms, namely:-daggershaped (cultratum), which occurs in lehthyophis (Epicrium), lies freely in the sheath and can be pushed out like the point of a trocar; valve-like (valvatum), placed at the orifice of the sheath and united to its hinder margin, so that it moves round upon this fixed basal part like a flap upon its hinge, although when protruded it appears somewhat spindle-shaped, as in Ccecilia tentaculata; and globular (globosum), which occurs in Gymnopis, and in which the thin basal part is situated in the bottom of the sheath. An intermediate form occurs in Cocilia (Herpele) squalostoma; it appears globular externally, but is attached by its extremity to the wall of 
the sheath, like the second form, but at a greater distance from the orifice.

With regard to the habits of the species, it appears that Chthonerpeton indistinetum and Hypographis rostratus have been found living in society at considerable depths in the earth; whilst other species were observed in the East Indies by Colonel Beddome under stones, and Typhlonectes compressiccudus and natans have been found swimming in fresh water. The branchiferous young of Ichthyophis glutinosus has also been taken in the water.

Prof. Peters gives the following Table of the genera:-

I. LePIDoc at least on the margins of the folds ; mandibular teeth in two rows.

A. Extremity of the body pointed; tentacle cultrate.

a. Body depressed; body-rings forming an angle in the middle of the belly; tentacular pit near the buccal margin, between eye and nostril ............

b. Body cylindrical; tentacular pit under

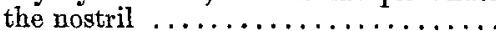

B. Extremity of the body rounded off.

a. Tentacular pit horseshoe-shaped; tentacle valvate.

* Tentacle under the nostril

1. Ichthyophis.

2. Urceotyphlus, g. $\mathbf{n}$.

+ Tentacle behind and under the nostril .

b. Tentacular pit circular; tentacle globate.

* Eyes visible, in an orbit ...........

+ Eyes invisible, under the cranial bones. a. Tentacular pit nearer the angle of the mouth than the nostril ......

$\beta$. Tentacular pit nearer the nostril than the angle of the mouth

II. Grmpoc 3. Cacitia.

4. Hypogeophis, g. n.

5. Dermophis, g. n.

6. Gymnopis.

7. IIerpele, g. $\mathbf{n}$.

like scales; tentacle valvate; tentacular pit horseshoe-shaped.

A. Extremity of the body rounded off.

a. Mandibular teeth biserial; tentacular pit midway between nostril and eye.....

b. Mandibular teeth uniserial; tentacular pit much nearer the eye than the nos-

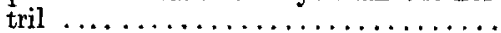

B. Extremity of the body compressed; mandibular teeth biserial; tentacular pit close behind the nostril

8. Chthomerpeton, g. $\mathrm{n}$.

9. Siphonops.

10. Typhlonectes, $\mathrm{g} . \mathrm{n}$.

The genus Ichthyophis, Fitzinger (=Epicrium, Wagler), includes three eastern species-namely, I. glutinosus, Iinn., I. monochrous, Bleek., and I. Beddomei, sp. n. Beddome's Epicrium carnosum, Gegenes carnosus, Günth., is regarded by Prof. Peters as founded upon very young, immature animals, which, from their cylindrical form and the position of the nostrils, seem to approach Cacilia rather than Ichthyophis. As the generic name Gegenes has long been pre- 
occupied, the author suggests Gegeneophis for the genus in the event of its proving to be well founded. Urceotyphlus has the tentacular pit circular and the base of the cultrate tentacle at the bottom of the tentacular tube. It includes two East-Indian speciesCacilia oxyura, Dum. \& Bibr., and C. malabarisa, Beddome. The genus Cocilia, as restricted, includes seven American speciesnamely, C. tentaculata, Linn., isthmica, Cope, gracilis, Shaw, pachynema, Günth., ochrocephala, Cope, polyzona, Fisch. (sp. n.), and Güntheri, sp. n. (=C. rostrata, Günth. non Cuv.). Hypogeophis has the eye visible; the species referred to it are Cacilia rostrata, Cuv., from the Seychelles, and C. Seraphini, Dum., from Gaboon and the Camaroons. Dermophis includes scaled species, which have been referred by previous authors to Wagler's genus Siphonops, founded upon the scaleless Cacilia annulata, Mikan. Prof. Peters refers to Dermophis the American species Siphonops mexicanus, Dum. \& Bibr., S. brasiliensis, Lütken, S. proximus, Cope, and S. simus, Cope, and the WestAfrican S. brevirostris, Pet., and S. thomensis, Bocage. Gymnopis closely approaches Siphonops in the structure of the skull. To this genus three American species are referred-namely, G. multiplicata, Pet., Rhinatrema unicolor, Dum., and Siphonops oligozona, Cope. Herpele, which approaches Coccilia in cranial structure, includes only one species, the West-African Ccecilia squalostoma, Stutchbury. In Chthonerpeton the tentacular pit is placed midway between eye and nostril, but considerably below the line joining those organs; the only known species is Siphonops indistinctus, Reinh. \& Lütk., from South America. The sole representative of the restricted genus Siphonops is Wagler's type species C. annulata, Mikan, from Brazil, Guiana, and Peru. Lastly, in Typhlonectes the eyes are distinct, and the anal aperture surrounded by a sort of sucking-disk. The species are all from South America-namely, Cocilia compressicauda, Dum. \& Bibr., C. dorsalis, Pet., C. natans, Fisch., and ? Siphonops syntremus, Cope. The foetal form has vesicular branchiæ. Prof. Peters's paper is illustrated with a plate elucidating the characters of the genera.-Monatsb. Akad. Wiss. Berl., November 1879, p. 924 .

\section{Histology, Development, and Origin of the Testis and Ovary in Cam- panularia angulata (Hincks). By M. J. FraIPont.}

The histological study of the three layers, ectoderm, intermediate lamella, and entoderm, of the body in Hydroids, leads to some new and important facts, of which a summary is here given.

The small nematocysts of the ectoderm of the tentacles are surrounded by a slight protoplasmic layer, often nucleolated and individualized, to which a palpocil corresponds. This relation is important from the physiological point of view, and that of the mode of action of the urticant organs.

The endoderm of the stolons in the vicinity of the pedicles of female gonangia (Campanularire angulata), and espocially in the branches ( $C$. flexuos $\alpha$ ), contains larger cells, having, on the one hand, 